\title{
A Study on the Socio-Economic Impact of Mining Ban on the Households in Goa's Mining Belt
}

\author{
Sheetal D. Arondekar ${ }^{1 *}$ and I. Bhanu Murthy ${ }^{2}$ \\ ${ }^{1}$ Assistant Professor in Commerce and Management, VVM's Shree Damodar College of Commerce and \\ Economics, Margao-Goa, India \\ ${ }^{2}$ Ex-Principal, VVM's Shree Damodar College of Commerce and Economics, Margao-Goa, India
}

\begin{abstract}
Mining is one of the economic activities practiced in the small state of Goa apart from agriculture, tourism and fishing. With the advent of mining activities in the areas, the practice of traditional occupations was difficult. Mining industry brings lucrative incomes but it also comes with a lot of environmental hazards. The protests and agitation that took place against rampant mining operations owing to the Chinese boom in the last decade compelled the Supreme Court to order ban in September, 2012. With this background the current study aims at assessing the impact of this ban on the socio-economic characteristics of the households in the mining belt of Goa. For the purpose, an interview schedule was forwarded to 256 respondents in the mining belt. The results of the paired sample t-test showed a significant difference in the economic status of the households in the mining regions. Standard deviation showed the wide disparities in the incomes. The study also revealed a change in the occupational structure. The study suggests the need to educate people about the nature of mining industry and thus a need to invest into alternate income avenues instead of entirely relying on the industry which is temporal.
\end{abstract}

Keywords: Ban, Characteristics, Households, Mining, Socio-Economic

\section{Introduction}

Goa is one of the most attractive tourist destinations, known for its beaches and scenic beauty all over the world. It lies on the West Coast of India. It is located between the parallels $15^{\circ}-47^{\prime}-59^{\prime \prime}$ and $14^{\circ}-53^{\prime}-57^{\prime \prime}$ of latitude north and between meridians $73^{\circ}-40^{\prime}-54^{\prime \prime}$ and $74^{\circ}-53^{\prime}-11^{\prime \prime}$ of longitudes east of Greenwich. It covers an area of around $3702 \mathrm{~km}^{2}$ with a population of over 14, 50,000 according to the Goa Census 2011. It has a high literacy rate of $87.50 \%$ and a high per capita income. The Portuguese ruled the state for a long span of 450 years and have left their imprint in parts of the state. Goa got liberated in 1961 from the Portuguese rule.

The main economic activities of the people in the state are agriculture, fishing, tourism and mining. Agriculture was a predominant occupation, but over a period due to various reasons this sector has seen a decline. According to TERI, (2012) the pattern of economy has shifted from agrarian based to manufacturing and tertiary forms as these sectors seem to be more lucrative. The state is rich in iron ore deposits. The natural harbour, navigable inland waterways, low taxation of minerals and liberal policy with respect to granting of

*Email: sheetaldnyan@rediffmail.com 
concession has favoured the growth of mining industry in the state.

The mining sector has witnessed a rapid growth in exports during the last decade, following the huge Chinese demand for iron ore. The exports went up from $17.09 \mathrm{mnts}$ in 2001-02 to $33.38 \mathrm{mnts}$ in 2006-07, the highest recorded in 2010-11 to the tune of $52.29 \mathrm{mnts}$ as shown in Table 1. The Goan ore ranges between 58\% to $62 \%$ ferrous content, while the domestic industries require a higher quality ore, hence the entire ore is exported. The rising demand for iron oreby China led to digging of every land that was not worth mining as China accepted the low grade ore of Goa. This led to rampant mining and illegalities in the sector. Although the mining sector contributed significantly to the states GDP from $9.36 \%$ in $2006-07$ to $19.87 \%$ in $2010-11$ it had also had adverse implications on the environment in the areas of operation. The result of all this was seen in the sudden ban in the iron ore mining industry in the state ordered by the Supreme court in September 2012.

All this had severe socio-economic impacts on the households in the mining regions and especially with

Table 1. Iron ore exports from Goa

\begin{tabular}{cc}
\hline Year & Quantity (in million tones) \\
\hline $2001-02$ & 17.09 \\
$2002-03$ & 21.02 \\
$2003-04$ & 27.46 \\
$2004-05$ & 28.12 \\
$2005-06$ & 31.11 \\
$2006-07$ & 33.38 \\
$2007-08$ & 33.60 \\
$2008-09$ & 39.46 \\
$2009-10$ & 45.95 \\
$2010-11$ & 52.29 \\
$2011-12$ & 41.79 \\
$2012-13$ & 11.10 \\
\hline
\end{tabular}

Source: Directorate of Mines and Geology, Goa respect to the occupational pattern and economic variables. Their financial position was affected to a great extent. Table 2 shows the contribution of mining sector and agricultural sector in the state's GDP. With an increase in the mining activities, there is a decline in the share of agriculture sector i.e., from $9.36 \%$ in 2006-07 the mining sector showed an increase in the contribution to GSDP upto $14.73 \%$ in 2011-12; while the agricultural sector showed a simultaneous decline from $4.61 \%$ in $2006-07$ to $2.91 \%$ in $2011-12$. But with a decline in the mining sector to $4.8 \%$ in $2012-13$ and further $4.16 \%$ in $2013-14$, the agricultural sector has shown an improvement to $3.21 \%$ in $2012-13$ and $3.74 \%$ in $2013-14$.

Iron ore mining in Goa is done by open cast method of extraction that has serious effects on the environment. In Goa to obtain $1 \mathrm{mnt}$ of iron ore around 2.5 to $3 \mathrm{mnts}$ of overburden has to be excavated resultingin problems of storage of dumps. This waste occupies more space than allotted to the mining companies for their operations. This accumulated silt enters the fields during rains making the lands unfit for cultivation. The mining industry requires water in huge quantities for backwashing of the ore. The mining dumps have resulted in a permanent damage of the local area. Mining is one of the major concerns causing land degradation as about 12,000 hectares have been rendered wastelands due to mining which is $3 \%$ of total geographical area (TERI, 2012).

The most affected in this scenario are the people living in the mining areas. They are directly exposed to the environment and thus have to face social and economic impacts of mining. Priyanath, (1999) reported a decline in the agriculture, seasonal unemployment, inequality in income and a decline in the standard of living due to mining activities in the areas of operation. Mendes, (2001) has revealed an improvement in the socioeconomic status of the households in the mining areas

Table 2. Contribution of mining and quarrying sector and agricultural sector in the State's GDP

\begin{tabular}{ccccccccc}
\hline Year & $2006-07$ & $2007-08$ & $2008-09$ & $2009-10$ & $2010-11$ & $2011-12$ & $2012-13$ & $2013-14$ \\
\hline Mining and Quarrying & 9.36 & 12.94 & 16.84 & 17.18 & 19.87 & 14.73 & 4.8 & 4.16 \\
Agricultural sector & 4.61 & 4.32 & 3.56 & 3.26 & 3.09 & 2.91 & 3.21 & 3.74 \\
\hline
\end{tabular}

Source: Directorate of Planning, Statistics and Evaluation, 2015 
when compared to the non-mining areas of the same taluka, at the same time he has also reported an adverse effect on their health. Noronha \& Nair, 2005 reported a lower satisfaction in the environmental domain in the mining regions compared to the non-mining regions in the Quality of Life (QOL) study conducted by them. Remy \& MacMahon, (2002) found that non-mine-related employment generated through multiplier effects is often much higher than direct or indirect employment in the mines. People around the large mines were at a gain in terms of training and education compared to the medium scale mines that limited their services to their own workforce. A study by Kitula, (2006) also revealed the same, that the locals in the region receive direct and indirect complimentary source of income from mining activities and improved infrastructural facilities. However, Kangwa, (2008) pointed out that productive lands are used for mining purposes instead of traditional purpose, that affects the social support system of the locals in the regions. He further added that the expansion in the mining activities leads to water and noise pollution and land degradation and that the revenues earned do not benefit the locals. Mengwe, (2010) also found the same, and further added that the closure of mines forces outward movement of the migrants who came into the regions in search of jobs. This is a great loss for the business people who are dependent on the migrants for their sale.

Thus mining industry comes with positive as well as negative socio-economic impacts for the households in the areas, but it is subject to the households' participation in the industry. While the households' directly or indirectly participating in the mining activities are benefited the others are affected, but in times of closure these participating households are the worst affected as they become highly dependent on the industry for their incomes.

In the wake of this, the current study aims at answering the following questions:

- Has mining ban brought about any change in the occupational structure of the households in the mining areas?

-What has been the impact of mining ban on the economic status of the households in the mining areas?
- What has been the impact of mining ban on the benefits availed and problems faced by the households in the mining areas?

\subsection{Study Area}

The iron ore deposits are located along the Western Ghats where most of the forests are confined. The four talukas: Bicholim and Sattari in North Goa and Sanguem and Quepem in South Goa largely fall in the mining belt. This accounts for almost $1 / 5^{\text {th }}$ of the area of Goa i.e, approximately $700 \mathrm{~km}^{2}$. The inhabitants in these areas were largely dependent on agriculture and forests for their livelihoods. But with mining industry there was a complete change in the occupational structure. From the point of view of mineral production Bicholim contributes almost $60 \%$ of the value of minerals followed by Sanguem. In terms of area under mining, maximum area is in Sanguem taluka followed by Bicholim, Sattari, and Quepem. Based on concentration the iron-ore deposits are divided into three parts: Northern zone, Central zone and Southern zone. The Northern zone is dominant in iron-ore, comprising of about $60 \%$ of the total iron-ore reserves of Goa while the Central zone comprises of both iron-ore and ferruginous manganese ore deposits.

\subsection{Objectives of the Study}

The study aims at covering the following objectives:

- To study the socio-economic profile of the respondents in the mining areas.

- To study the impact of iron ore mining ban on the socio-economic characteristics of the households in the mining areas.

- To study the impact of mining ban on the benefits availed by the households in the mining areas and the problems faced by them.

\subsection{Hypothesis}

The study aims at testing the following hypothesis:

- $\mathrm{H}_{0}$ : There is no significant difference in the incomes of the households in the mining regions of Goa before and after mining ban.

- $\mathrm{H}_{0}$ : There is no significant difference in the monthly expenditure of the households in the mining regions of Goa before and after mining ban. 
- $\mathrm{H}_{0}$ : There is no significant difference in the investment of the households in the mining regions of Goa before and after mining ban.

- $\mathrm{H}_{0}$ : There is no significant difference in the monthly expenditure on medicines of the households in the mining regions of Goa before and after mining ban.

\subsection{Research Methodology}

The study used the primary and the secondary sources of data. The primary data collection was done using an interview schedule during the period October 2013 upto May 2014. It comprised of the socio-economic profile of the respondents and the benefits and problems due to mining practices in the area. The schedule was administered to a random sample of 300 households of age 18 years and above from mining villages in the four talukas. Of these $256(85 \%)$ was found suitable for the purpose of analysis. Frequency tables, means and standard deviations were used to analyse the socio-economic variables using the statistical package SPSS 16. Paired sample t-test was used to compare the socio-economic characteristics of the households before and after mining ban after meeting the normality conditions. The secondary data was collected through various Government reports, newspaper articles and discussions with the Village Panchayat members, Green activists, Government Officials in the Ministry and academicians.

\section{Analysis and Discussion}

\subsection{Socio-Demographic Profile of the Respondents}

Table 3 gives the brief profile of the respondents in the mining areas. A higher number of respondents i.e. 55\% were females and the rest $45 \%$ were males. Forty three percent of the respondents were of the age between $18-40$ years, $47 \%$ and the remaining $9 \%$ were respectively between age groups 40-60 years and 60 years and above groups.

As far as marital status is concerned $71 \%$ were married. $17 \%$ of the households lived for up to 20 years at the current place of residence, $13 \%$ lived in between 20-40 years and the rest $70 \%$ lived for more than 40 years.
Table 3. Socio-demographic profile of respondents

\begin{tabular}{|c|c|c|c|}
\hline Sr. No. & $\begin{array}{l}\text { Socio-demographic } \\
\text { characteristics }\end{array}$ & Frequency & $\%$ \\
\hline \multirow[t]{4}{*}{ A } & \multicolumn{3}{|c|}{ Gender } \\
\hline & Female & 141 & 55.1 \\
\hline & Male & 115 & 44.9 \\
\hline & Total & 256 & 100 \\
\hline \multirow[t]{5}{*}{ B } & \multicolumn{3}{|c|}{ Age } \\
\hline & $18-40$ & 111 & 43.4 \\
\hline & $40-60$ & 121 & 47.2 \\
\hline & Above 60 & 24 & 9.4 \\
\hline & Total & 256 & 100 \\
\hline \multirow[t]{4}{*}{ C } & \multicolumn{3}{|c|}{ Marital Status } \\
\hline & Married & 181 & 70.7 \\
\hline & Others & 75 & 29.3 \\
\hline & Total & 256 & 100.0 \\
\hline \multirow[t]{5}{*}{ D } & \multicolumn{3}{|c|}{ Length of residence } \\
\hline & Less than 20 years & 43 & 16.8 \\
\hline & $20-40$ years & 34 & 13.3 \\
\hline & More than 40 years & 179 & 69.9 \\
\hline & Total & 256 & 100.0 \\
\hline \multirow[t]{8}{*}{$E$} & \multicolumn{3}{|c|}{ Educational Status } \\
\hline & Illiterate & 34 & 13.3 \\
\hline & Upto primary & 20 & 7.8 \\
\hline & Upto secondary & 44 & 17.2 \\
\hline & SSC & 62 & 24.2 \\
\hline & $\begin{array}{l}\text { Higher secondary/vocational/ } \\
\text { diploma }\end{array}$ & 76 & 29.7 \\
\hline & Graduation & 20 & 7.8 \\
\hline & Total & 256 & 100.0 \\
\hline
\end{tabular}

Source: Primary Survey

With respect to education, $13 \%$ of the respondents were illiterate, $8 \%$ perceived their primary education, $17 \%$ had done up to secondary, $24 \%$ were SSC cleared, $30 \%$ have done their higher secondary education and only $8 \%$ were graduates.

\subsection{Impact of Mining Ban on the Socio-Economic Status of the Households in the Mining Areas}

\subsubsection{Occupation}

Table 4 gives the details of the occupational status of the mining companies in the agricultural areas and forest areas. Thus, these people are especially close to households in the mining areas before and after the ban. Although agriculture was the main occupation of 
Table 4. Occupational status of households in the mining regions before and after mining ban

\begin{tabular}{|c|c|c|c|c|}
\hline \multirow{2}{*}{$\begin{array}{l}\text { Occupational } \\
\text { status(*) }\end{array}$} & \multicolumn{2}{|c|}{ Before Ban } & \multicolumn{2}{|c|}{ After Ban } \\
\hline & $\begin{array}{c}\text { No. of } \\
\text { Households }\end{array}$ & $\%$ & $\begin{array}{c}\text { No. of } \\
\text { Households }\end{array}$ & $\%$ \\
\hline $\begin{array}{l}\text { Agriculture and } \\
\text { allied activities }\end{array}$ & 50 & 19.5 & 62 & 24.2 \\
\hline Labor & 44 & 17.2 & 25 & 9.8 \\
\hline Service & 137 & 53.5 & 118 & 46.1 \\
\hline $\begin{array}{l}\text { Trade/Business/ } \\
\text { Profession }\end{array}$ & 119 & 46.5 & 51 & 19.9 \\
\hline
\end{tabular}

Source: Primary Survey

( ${ }^{\star}$ Total will be more than $100 \%$ since households may be practicing more than one occupation)

the people in the areas and sale of forest products, mining expansion after Chinese boom led to encroachment the mines could not practice agriculture. The ones away from mines took up agriculture only for selfconsumption as the yield was low fetching them very little or no income. As a result, there was less scope for agricultural labour as well but the mining labour did have scope in the area.

Service here includes people working in the mining companies, government undertaking and other private companies. Although mining came with job opportunities in the area getting people with required skills was difficult, hence very few could be absorbed by the company. As far as trade/business is concerned lot many opportunities were created on expansion of mining in the areas. There was migration of people with their families into the areas, thus there was need for housing and food. Thus households in the areas let out their rooms on rent, established tea stalls, fruit and vegetable stalls, small grocery shops, etc. Households that could not practice agriculture were given a contract of trucks and other mining machinery by the mining companies by making loan arrangements' for them and hiring their trucks. Thus there was large scope for the garage shop as well. Households were involved in more than one occupation. In fact, some of the households also invested into mining companies as an alternate source of income by letting trucks as it fetched them high and direct income.

From the above it is evident that most of the households were directly and indirectly dependent on the mines for their livelihoods. There was a change in the occupational pattern from agriculture to other occupation as that seemed to be more lucrative than agriculture.

The post ban period however, tremendously affected the mining dependent. Closing of mines left the labourers jobless, temporarily employed people were also jobless, trade and business witnessed a decline and some businesses had to be shut down. But the agriculture showed a positive change with people diverting to this sector left with no other source of living. Thus agriculture has seen an increase from $19.5 \%$ to $24.2 \%$, while labour has seen a decline by $7.4 \%$, service sector by $7.4 \%$ and trade and business by $26.6 \%$. Further the decline in labour is negligible due to the fact that there is shift of the labour from mining to agriculture. Besides, people working for mining companies are out of job while there has been no impact on the other service people and there were some who have shifted from mining companies to other companies for job. There were instances where people wanted to revert to agriculture but the permanent damage that mining had left on their lands discouraged them to do so.

\subsubsection{Economic Status}

The pre-mining phase has seen an increase in the incomes of the households, with a simultaneous increase in the monthly expenditure, savings according to the opinion of the people. But it is also coupled with an increase in their medical expenses as they are exposed to the harmful environmental effects of mining and thus suffer from respiratory and other sicknesses. Although the mining companies have extended medical support, yet it was observed that this support is provided mainly to those directly working for the mining companies.

The post mining phase has seen a decline in the monthly incomes thereby a decline in the monthly expenditure and savings. The average monthly income has dropped from Rs. 56,140 to Rs. 21,150, average monthly expenditure from Rs. 8,520 to Rs. 7,990, monthly savings from Rs. 2,820 to Rs. 1,260 while the average medical expenses show an average decline by Rs. 170 per month (Table 5). The positive impact of the ban has been a decline in the medical expenditure due to no 
Table 5. Descriptive statistic

\begin{tabular}{|c|c|c|c|c|}
\hline Variables & Mean(Rs.) & Standard deviation(Rs.) & Minimum(Rs.) & Maximum(Rs.) \\
\hline \multicolumn{5}{|c|}{ Before Mining Ban } \\
\hline Total Monthly Income & 56,140 & 98,910 & 1500 & 1230000 \\
\hline Monthly Expenditure & 8520 & 4800 & 300 & 30000 \\
\hline Monthly Savings & 2820 & 4580 & 0 & 30000 \\
\hline Monthly Medical Expenditure & 480 & 2280 & 0 & 30000 \\
\hline \multicolumn{5}{|c|}{ After Mining Ban } \\
\hline Total Monthly Income & 21150 & 29030 & 0 & 352000 \\
\hline Monthly Expenditure & 7990 & 4490 & 500 & 32000 \\
\hline Monthly Savings & 1260 & 2270 & 0 & 14000 \\
\hline Monthly Medical Expenditure & 310 & 1210 & 0 & 11000 \\
\hline
\end{tabular}

Source: Primary Survey

exposure to the harmful environment. The data shows wide disparity in the monthly income with a standard deviation of Rs. 98,910. The incomes earned by the households directly into mining activities as well as the ones into trade/business were higher compared to the others. But with the mining ban these households were badly affected. Thus it would be apt to say here that the mining ban has affected the incomes of the households in the mining areas.

In this case the other most important variable that has affected the socio-economic status of the households is the loan liability. As showed in Figure 1, 43\% of the households had taken loans before the ban whereas $11 \%$ had taken after the ban.

111 households (i.e., $43 \%$ ) had taken loan, of which 4 households had taken for agricultural purpose; 50 for house repair/renovation and purchase of vehicle; 39 for business purpose (purchase of trucks) and 18 for other purposes not mentioned above (Table 7).

The average loan instalment paid each month is Rs. 15,365 while the standard deviation is Rs. 46,663 again depicting a huge variation in the loan liabilities. The direct income that people were receiving due to mining operations gave them courage to raise huge loans. Loan amounts of less than Rs. 20,000 per month were used for house repair/renovation, agricultural purpose, petty businesses and marriages; while loans of Rs. 20,000 and above per month were used for payment towards vehicles, tipper trucks and mining equipment.
Figure 1. Loan taken by the households. Source: Primary Survey

Table 6. Monthly loan instalment

\begin{tabular}{cc}
\hline $\begin{array}{c}\text { Variable } \\
\text { Monthly loan instalment }\end{array}$ & Mining $(\mathrm{N}=256)$ \\
\hline 0 & $117(45.7)$ \\
Upto Rs.20,000 & $87(34)$ \\
Rs.20,001 and above & $52(20.3)$ \\
Total & $256(100)$ \\
\hline
\end{tabular}

Table 7. Purpose of loan

\begin{tabular}{ccc}
\hline Purpose of loan & Frequency(Before ban) & Frequency(After ban) \\
\hline Agricultural purpose & 4 & 0 \\
Personal & 50 & 14 \\
Business & 39 & 1 \\
Others & 18 & 10 \\
Total & 111 & 25 \\
\hline
\end{tabular}

Source: Primary data

While after the mining ban, $11 \%$ had taken loans, of which 14 households availed of the loan for house repair/renovation and purchase of vehicle; only 1 for business purpose and 10 households for other purpose. 
The mining ban had an adverse effect on the incomes of the households and thus they were unable to repay the loans. According to the findings, around 35\% (i.e., 89) of the surveyed households had tipper trucks hired by the mining companies for the mining purpose. Of these 49 households owned one truck while 40 households owned more than one truck. Especially the people who had recently purchased trucks were not in a position to generate any income to repay their loans.

\subsubsection{Benefits Availed and Problems Faced due to Mining Operations}

As part of their Corporate Social Responsibility (CSR) the mining companies extended developmental facilities to the households in the mining areas. $61 \%$ of the households availed the medical facilities, $18 \%$ were employed by the companies, around $43 \%$ of the households children were provided with educational support by way of free books, uniforms, umbrellas, etc. thereby reducing parents expenses on education. Also scholarships for the employees' children were provided by the mining companies. Around 16\%, received compensation for giving up their lands, another $12 \%$ feel that

Table 8. Defaulters of loan

\begin{tabular}{ccc}
\hline & Defaulters & \\
\hline Response & Frequency & $\%$ \\
Yes & 69 & 27 \\
No & 67 & 26 \\
& 136 & 53 \\
Before Ban & Period of default & \\
After Ban & 5 & 2 \\
& 64 & 25 \\
\hline
\end{tabular}

Source: Primary data

Table 9. Benefits due to mining in the areas

\begin{tabular}{ccc}
\hline Benefits provided & No. of households & $\%$ \\
\hline $\begin{array}{c}\text { Improved medical facilities } \\
\text { Job preferences/Business opportunities/ }\end{array}$ & 156 & 60.9 \\
Created income avenues & 46 & 18 \\
Educational support & 110 & 43 \\
Compensation & 41 & 16 \\
Improved infrastructure & 30 & 12 \\
Other benefits & 44 & 17.2 \\
\hline
\end{tabular}

Source: Primary data

http://www.informaticsjournals.com/index.php/sdmimd | Vol 8 | Issue 1 | March 2017 mining has led to improvement in the infrastructure of the area and $17 \%$ availed of other benefits due to mining. But over a period of time, with the mining ban these benefits were declining.

Decline in the educational support has seen a drop in the attendance of children in school of the mine employed (www.csr21.org/content/goan-communities-demand-more-mining, 2014). The major iron ore producing company Vedanta has shut down its senior football academy, its technical school as a measure to cut the costs along with a decline in the other areas of developmental activities (www.timesofindia.com/ city/goa/Mining-closure-Vedanta-CSRactivities/ articleshow/46973174.cm, 2005).

No initiatives have been taken by the mining companies to protect the jobless due to mining ban. No alternatives had been offered or provided by the mining companies to overcome their financial difficulties and social problems.

Table 10 gives the list of problems people faced due to mining activities in the mining regions. But with the suspension of mining activities, they have slowly vanished. The reports from various agencies points out that mining has left permanent damage to their lands and people are finding it difficult to revert to agriculture. All the villages in Bicholim are affected, the paddy

Table 10. Other impacts of the mining activities

\begin{tabular}{ccc}
\hline Mining impacts & Mining areas \\
& No. of Households & $(\%)$ \\
\hline Traffic congestion/road accidents & 149 & 58 \\
Death in the family due to road accidents & 2 & 0.8 \\
Major disability due to accident & 2 & 0.8 \\
Minor disability due to accident & 4 & 1.6 \\
Respiratory sicknesses and other health & 37 & 14.5 \\
problems & 122 & 47.7 \\
Water problems & 225 & 87.9 \\
Pollution & 107 & 41.8 \\
Agricultural land affected & 21 & 8 \\
Cracks on walls and floor & 23 & 9 \\
Inflow of migrants & 34 & 13.3 \\
Any other &
\end{tabular}

Source: Primary data 
Table 11. Results of paired sample t-test

\begin{tabular}{llccc}
\hline & Paired Sample Test & t & Sig. (2-tailed) & Result \\
\hline Pair 1 & $\begin{array}{c}\text { total income bef ban - total } \\
\text { income af ban }\end{array}$ & 5.892 & $.000^{*}$ & Reject \\
Pair 2 & $\begin{array}{c}\text { household expenditure } \\
\text { bef ban - household } \\
\text { expenditure af ban }\end{array}$ & 3.199 & $.002^{\star}$ & Reject \\
Pair 3 & $\begin{array}{c}\text { investment bef ban - } \\
\text { investment af ban }\end{array}$ & 6.228 & $.000^{\star}$ & Reject \\
Pair 4 & $\begin{array}{l}\text { monthly expenditure } \\
\text { on medicines bef ban - } \\
\text { monthly expenditure on } \\
\text { medicines af ban }\end{array}$ & 2.030 & $.043^{*}$ & Reject \\
\hline
\end{tabular}

*Significant at 95\% confidence level Sample Size:256 Source: Primary data

fields are rendered useless for cultivation, choked with mining rejects, and dairy farming is also unsustainable as there is no fodder or adequate water according to Ramesh Gawas (News, 2012).

\section{Results of Hypotheses Testing}

The results of the paired sample t-test and the discussion held do not support the null hypothesis. Thus the null hypothesis is rejected and alternate hypothesis is accepted that there has been a significant difference in the economic variables of the households in the mining areas before and after mining ban.

From the results above it can be said that the mining industry was a flourishing one and gave lucrative incomes to its dependents but its closure had a severe blow on their socio-economic characteristics. This needs a serious attention because had the people been trained to diversify into other income avenues they would have been able to sustain their incomes and not lose it completely. This is a lesson for the society that lucrative incomes need not mean sustainable income and mining industry is not here to stay forever. Every industry is expected to conduct an ethical business and bring about development in the areas of operation but the mining industry had left the local in a worse off condition to handle their problems for themselves. This behaviour of the mining industry towards the locals, at the cost of whom they have been operating into the area, risking their traditional income sources and exposing them to the worst of environment is not an acceptable one.

\section{Conclusion and Suggestions}

The closure of mining industry had many positive as well as negative impacts on the households in the mining regions. With the expansion of mining activities since lands were rendered uncultivable people were forced to give up agriculture, thereby losing their source of livelihoods. Besides, the profits that people earned from mining related activities outweighed the earnings from agriculture. In most of the areas, households purchased trucks and used them for the transportation of ore. Migration due to mining activities had led to business avenues for the households which was lost after the ban. Households were largely reliant on the mining operations; however the industry could not support the people's livelihoods. Thus there was a change in the occupational structure. The investment into mining seemed to be so lucrative that more and more people purchased trucks; there was a rise in their living standards with high incomes, high expenditures and good savings, but the sudden ban left people with the mounting loan liabilities which they were not able to repay after the stoppage of mining activities. The economic status of the mining dependent was very much adversely affected. Over a period of time the benefits in the name of CSR activities which were forwarded to the people in the areas showed a decline and vanished after no signs of mining revival. However the positive outcomes i.e. improvement in the environment quality, health and a revival of agriculture; in some parts of the mining belt were observed.

Mining had also come with some extended educational, medical and infrastructural facilities for the people, but the extent of this was based on the size and scale of operations of the mining company and the involvement of people in the mining activities. No uniformity in was maintained. Thus, though benefits as part of CSR were provided to the households not all could avail of the same. Above all the compensations that were paid to the households were unfair and very low, not enough to make up a proper living. While the large companies did help contribute towards the developmental activities of the mining areas, the small and medium sized companies were not serious with regards to the same. The study reveals that mining could not sustain the livelihoods of the households in the area after the ban. 
The Government may form agreement with the mining companies to take appropriate preventive and control environmental measures as well as sharing the revenues of mineral exploitation with the population in the areas. A continuous monitoring by every department and a cordial relations amongst them may aid in solve environmental issues. Even though the state has high a literacy rate, the mining belt lies in an educationally backward area, thus an initiative may be taken by the mining industry in association with the government in promoting higher education. The households may also be educated about the very nature of the industry i.e. non-renewable, so that they do not rely solely on this industry for their livelihoods. As Balanay, et al., (2014) suggests that mining has positive impact on income and the capability to improve the standard of living of people in the areas if proper investments are made into human capital building and entrepreneurship.

The study may be of help to the government policy makers whilst planning their strategies keeping into consideration the positive and negative effect mining industry has on the social and economic characteristics of the households in the areas.

\section{References}

Balanay, R. M., Yorobe Jr., J. M., Reyes, S. G., Castanos, A. M., Maglente, O. K., Panduyos, J. B., et al. (2014, June). Analyzing the income effects of mining with international variables for poverty reduction implications in Caraga region, Philippines. Journal of International and Global Economic Studies, 7(1), 20-31.

Directorate of Planning, Statistics and Evaluation. (2015). Economic Survey 2014-15. Porvorim, Goa: Government of Goa.
Kangwa, P. K. (2008).An Assessment of the Economic, Social and Environmental Impacts of the Mining Industry: A Case Study of Copper Mining in Zambia. Dissertation, LUND University, Social and Economic Geography.

Kitula, A. G. (2006). The Environmental and Socioeconomic Impacts of Mining on Local Livelihoods in Tanzania: A Case Study of Geita District. Journal of Cleaner Production, 14, 405-414. Retrived from: https:// doi.org/10.1016/j.jclepro.2004.01.012

Mendes, G. (2001). A Socio-Economic Analysis of Mining Industry: A Case Study of Bicholim Taluka in Goa. Ph.D Thesis, Utkal University, Dept. of Economics.

Mengwe, M. S. (2010). Towards Social Impact Assessment of Copper-Nickel Mining in Botswana. Thesis, Nelson Mandela Metropolitan University, Faculty of Science.

News, H. G. (2012, October 10th). www.goa4u. com/2012/10/12/agriculture-bites-the-dust-in-themining-talukas. Retrieved October 7th, 2016.

Noronha, L., \& Nair, S. (2005). Assessing Quality of Life in a Mining Region. Economic \& Political Weekly, 4(1), 72-78.

Priyanath, H. (1999). Socio-economic and Environmental Impact of Gem Mining Industry in Sri Lanka: A Case Study of Hunuwala village in Ratnapura District. Sabaragumawa University Journal, 2(1), 101-109.

Remy, F., \& MacMahon, G. (2002). Large Mines and Local Communities: Forging Partnerships, Building Sustainability. World Bank and International Finance Corporation. World Bank Group's Mining Department.

TERI. (2012). Directions, Innovation and Strategies for Sustainable Development in Goa-Executive Summary. New Delhi: The Energy and Resources Institute. 29pp. [Project Report No. 2010EE02].

www.csr21.org/content/goan-communities-demandmore-mining. (2014, June 13). Retrieved October 7th, 2016.

www.timesofindia.com/city/goa/Mining-closureVedanta-CSR activities/articleshow/46973174.cm. (2005, April 19). Retrieved October 7th, 2016. 
